\title{
Pencegahan Penyakit Toxoplasmosis Melalui Video Animasi Lagu Edukasi Pada Anak Di Desa Drajat Kecamatan Baureno Kabupaten Bojonegoro
}

\author{
Lailia Dwi Kusuma Wardhani ${ }^{1 *}$, Nabila Azaria Hutomo², Bima Satria \\ Moekti $^{3}$, Mega Utami Eka Mukti ${ }^{4}$ \\ ${ }^{1}$ Departemen Anatomi, Fakultas Kedokteran Hewan Universitas Wijaya Kusuma \\ Surabaya \\ ${ }^{234}$ Fakultas Kedokteran Hewan Universitas Wijaya Kusuma Surabaya \\ Email : lailia.wardhani26@gmail.com
}

\section{Article History: \\ Received: November 2020 \\ Revised: Januri 2021 \\ Accepted: Juni 2021 \\ Available online: Juni 2021}

\section{Kata Kunci: \\ anak, edukasi, toxolasmosis, video animasi edukasi}

\begin{abstract}
Abstrak:
Toxoplasmosis merupakan penyakit infeksi parasit protozoa yang disebabkan oleh Toxoplasma gondii. Kucing adalah inang definitif penyakit Toxoplasmosis. Penularan Toxoplasmosis melalui termakannya ookista dari feses yang mengkontaminasi lingkungan. Tingkat infeksi Toxoplasmosis di Indonesia masih cukup tinggi. Anak usia $2-5$ tahun suka bermain diluar rumah bersama hewan dan juga cenderung menyukai video animasi lagu. Kegiatan ini bertujuan untuk memberikan edukasi pencegahan penyakit Toxoplasmosis melalui video animasi lagu pada anak - anak. Agar anak - anak yang sering bermain diluar rumah dapat melakukan tindakan pencegahan terutama dari infeksi Toxoplasmosis. Sebanyak 50 anak di Desa Drajat Bojonegoro sebagai peserta dan didampingi orang tua atau wali. Bentuk kegiatan secara offline dan online dengan kegiatan penyampaian informasi dan video animasi lagu edukasi serta pengisian kuisioner. Kegiatan ini mendapat respon yang baik dari peserta dengan sebanyak lebih dari $64 \%$ menyatakan video ini edukatif, menarik dan informatif. Adanya video animasi edukasi ini dapat mencegah penularan penyakit Toxolasmosis
\end{abstract}




\section{Pendahuluan}

Indonesia adalah negara yang beriklim tropis. Negara iklim tropis memiliki tingkat kelembapan tinggi serta suhu udara yang ideal untuk pertumbuhan mikroorganisme baik bakteri, virus dan protozoa. Tingkat pertumbuhan mikroorganisme yang tinggi akan berdampak terhadap kesehatan masyarakat karena agen penyakit yaitu mikroorganisme dapat tumbuh dengan baik. Menurut Rachmawati (2019) Indonesia sebagai Negara tropis memiliki banyak permasalahan penyakit yang endemik pada hewan maupun manusia. Penyakit endemik dapat berupa penyakit zoonosis. Penyakit zoonosis adalah penyakit yang dapat menular dari hewan ke manusia atau sebaliknya (Ariyanto dan Eidar, 2018). Penyakit zoonosis menimbulkan kerugian ekonomi serta korban jiwa. Salah satu penyakit zoonosis di indonesia adalah Toxoplasmosis.

Toxoplasmosis merupakan penyakit infeksi parasit protozoa yang disebabkan oleh protozoa bersel satu yaitu Toxoplasma gondii. Golongan hewan felidae atau kucing adalah inang definitif penyakit Toxoplasmosis (Dwinata et al., 2018). Penularan Toxoplasmosis dapat secara horizontal dan vertikal. Penularan horizontal Toxoplasmosis melalui termakannya ookista dari feses yang mengkontaminasi lingkungan. Penularan juga bisa melalui konsusmsi daging mentah atau setengah matang, sayuran mentah dan buahbuahan yang terkontaminasi agen penyebab penyakit toxoplasmosis (Aditama et al., 2016). Penularan secara vertikal melalui ibu kepada janin. Gejala klinis akibat infeksi Toxoplasmosis tidak spesifk. Penderita Toxoplasmosis terkadang asimptomatis atau tidak menampakan gejala penyakit sehingga tidak berbahaya tetapi untuk penderita yang sistim imun buruk dan ibu hamil maka dapat timbul gejala penyakit. Gejala penyakit Toxoplasmosis mirip dengan gejala penyakit virus seperti lesu, sakit kepala, demam, nyeri otot, nyeri pada perut, sakit tenggorokan, hepatospeno-megali dan bercak merah di kulit (Sulistyawati \& Defa, 2018). Pencegahan Toxoplasmosis yaitu dengan mencegah termakannya ookista maupun kista, caranya adalah mencuci tangan setelah beraktifitas dengan kucing, mencuci tangan sebelum makan, mencuci buah dan sayur dengan air bersih dan memasak daging hingga matang. 
Tingkat infeksi Toxoplasmosis di Indonesia cukup tinggi. Menurut penelitian Tuda et al., (2017) Di Indonesia, sekitar 2-51\% penduduknya terinfeksi Toksoplasmosis yang terbagi di beberapa daerah yaitu $58 \%$ di Sulawesi Utara, 10-12\% di Jakarta, 9\% di Surabaya, 20\% di Yogyakarta, 2\% di Boyolali, 51\% di Jawa Barat, 9\% di Sumatera Utara, 3\% di Kalimantan Barat, 31\% di Kalimantan Selatan, 27\% di Sulawesi Tengah dan 16\% di Palu. Salah satu upaya penanggulangan Toxoplasmosis di Indonesia adalah edukasi pencegahan suatu penyakit menular. Edukasi berperan penting dalam upaya pencegahan penularan penyakit Toxoplasmosis. Menurut penelitian Sari \& I made (2017) terhadap tingkat pengetahuan remaja putri mengenai pencegahan Toxoplamosis, didapatkan hasil gambaran pengetahuan remaja putri cukup rendah, sehingga diperlukan edukasi mengenai pencegahan Toxoplasmosis.

Anak-anak khususnya usia 2-5 tahun memiliki kebutuhan bermain dan belajar. Perkembangan anak pada tahun-tahun pertama sangat penting karena menentukan kualitas anak di masa depan (Hasanah, 2016). Dunia anak adalah dunia bermain. Maka dari itu hendaknya upaya pengembangan diri anak usia 2-5 tahun melalui kegiatan belajar yang menyenangkan yang membuat anak seakan-akan bermain. salah satu contoh kegiatan belajar yang menyenangkan adalah belajar melalui media audiovisual yaitu video. Video bagi anak-anak sangat disukai karena dianggap menarik dan tidak membosankan (Ekowati et al., 2019).

Berdasarkan uraian diatas penulis melakukan kegiatan bertujuan untuk mencegah penyakit Toxoplasmosis melalui edukasi menggunakan media video animasi lagu pada anak-anak. Agar anak - anak yang sering bermain diluar rumah terutama dengan hewan kucing dapat melakukan tindakan pencegahan penularan Toxoplasmosis.

\section{Metode}

Tempat, Waktu dan Peserta

Kegiatan ini dilaksanakan pada tanggal 20 - 22 November 2020 dengan peserta yakni anak - anak usia 2-5 tahun di Desa Drajat Kecamatan Baureno Kabupat Bojonegoro. Peserta kegiatan juga melibatkan orang tua atau wali. 
Alat dan Bahan

Alat dan bahan yang digunakan pada kegiatan ini adalah video lagu animasi edukasi toxoplasmosis, kuisioner, bolpoin.

Bentuk Kegiatan

Kegiatan ini diawali dengan peneliti membuat video animasi lagu edukasi. Pelaksaan kegiatan dengan dua cara yaitu dengan offline dan online. Kegiatan offline dengan mendatangi beberapa tempat tinggal peserta sebanyak $60 \%$ dari jumlah peserta, kemudian ditunjukkan video lagu animasi edukasi toxoplasmosis. Sementara kegiatan online dengan membagikan alamat laman youtube video lagu animasi edukasi toxoplasmosis (https://www.youtube.com/watch?v=NfLiQnoqtZk) melalui aplikasi whatsapp orang tua atau wali peserta. Sebelum dilakukan kegiatan penyampaian video lagu animasi edukasi toxoplasmosis, diawali dengan penyampaian informasi terkait toxoplasmosis secara umum. Akhir dari kegiatan ini dilakukan dengan pengisian kuisioner oleh seluruh peserta dengan didampingi orang tua atau wali.

\section{Hasil}

Kegiatan pencegahan penularan penyakit toxoplasmosis melalui video animasi lagu edukasi di Desa Drajat Kecamatan Baureno Kabupaten Bojonegoro diikuti oleh 50 peserta. Rincian peserta disampaikan pada Tabel 1.

Tabel 1. Data Peserta Kegiatan Edukasi Toxoplasmosis Desa Drajat Kecamatan Baureno Kabupaten Bojonegoro

\begin{tabular}{ccc}
\hline Dusun & Tanggal Pelaksanaan & Jumlah Peserta \\
\hline Dradahan & 20 November 2020 & 21 anak \\
\hline Kreket & 21 November 2020 & 8 anak \\
\hline Mantup & 22 November 2020 & 21 anak \\
\hline
\end{tabular}


Hasil dari kegiatan ini mendapat respon yang baik dari peserta maupun orang tua atau wali peserta, hal ini diperkuat dengan hasil kuisioner. Hasil pengisian kuisioner terhadap 50 peserta kemudian dianalisis secara deskriptif. Didapatkan hasil sebesar $64 \%$ mengatakan bahwa video lagu animasi edukasi Toxoplasmosis ini menarik, sebanyak $75 \%$ peserta menyatakan video lagu animasi edukasi Toxoplasmosis ini informatif. Sementara itu sebanyak $94 \%$ peserta bersedia melakukan kegiatan kesehatan yang tertera pada video dan sebanyak $100 \%$ peserta juga bersedia memberikan informasi kesehatan Toxoplasmosis kepada orang lain.

\section{Diskusi}

Kegiatan pencegahan penularan penyakit Toxoplasmosis melalui video animasi lagu edukasi di Desa Drajat Kecamatan Baureno Kabupaten Bojonegoro berfokus pada anak - anak usia $2-5$ tahun dikarenakan pada usia tersebut anak - anak suka beraktifitas di luar rumah serta bermain dengan hewan salah satunya dengan kucing.

Kegiatan ini terdiri dari dua bentuk yaitu dengan offline dan online. Sebelum dilakukan kegiatan penyampaian video lagu animasi edukasi toxoplasmosis, diawali dengan penyampaian informasi terkait toxoplasmosis secara umum mulai dari hewan sebagai inang definif dan cara penyebarannya. Kegiatan offline dengan mendatangi beberapa tempat tinggal peserta, kemudian ditunjukkan video lagu animasi edukasi toxoplasmosis. Sementara kegiatan online dengan membagikan alamat laman youtube video lagu animasi edukasi toxoplasmosis melalui aplikasi whatsapp orang tua atau wali peserta. Baik dari kegiatan offline maupun online, peserta didampingi orang tua atau wali. Saat diperdengarkan video animasi lagu edukasi Toxoplasmosis, peserta senang karena mendapati lagu baru yang jarang mereka dengar. Beberapa dari peserta bahkan juga mengulangi lagu tersebut dan banyak yang sudah hafal liriknya. 


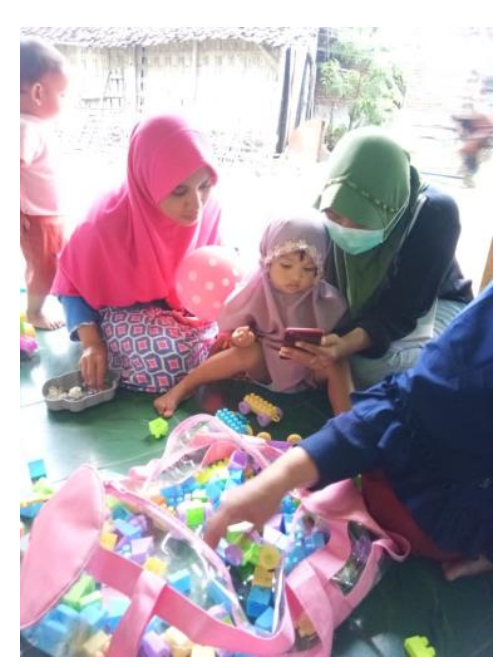

(A)

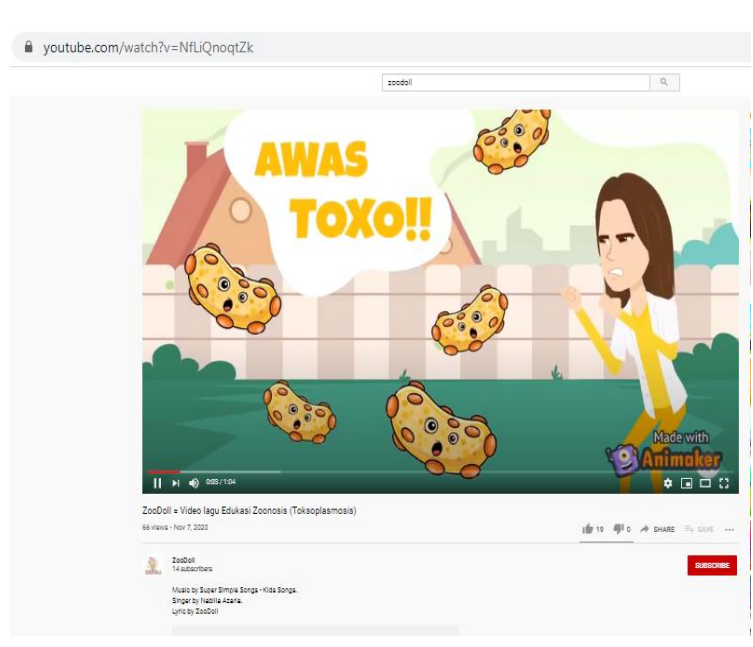

(B)

Gambar 1. Dokumentasi Kegiatan.

Keterangan : (A) Kegiatan offline

(B) Video lagu animasi edukasi Toxoplasmosis lewat kanal youtube (online)

Akhir dari kegiatan ini dilakukan dengan pengisian kuisioner oleh seluruh peserta dengan didampingi orang tua atau wali atau peserta yang belum bisa membaca dibantu mengisi oleh orang tua atau wali. Hasil kuisioner didapatkan bahwa video animasi lagu edukasi Toxoplasmosis ini menarik dan informatif, sehingga anak - anak menyukai video tersebut. Selain itu, anak - anak juga mau melakukan anjuran kesehatan yang telah disampaikan di video tersebut dan juga akan memberikan informasi kepada teman - teman yang lain. Respon baik juga didapat dari orang tua maupun wali. Mereka menyukai video animasi lagu edukasi Toxoplasmosis ini karena menambah dan mempermudah dalam mengedukasi anak - anak terutama di bidang kesehatan, dimana saat ini jarang terdapat video edukasi yang menarik kepada anak - anak terkait kesehatan. Orang tua atau wali anak - anak (peserta) juga memberi saran untuk penambahan video animasi lagu edukasi kesehatan bagi anak - anak di bidang kesehatan yang lain. 


\section{Kesimpulan}

Kegiatan pencegahan penularan penyakit toxoplasmosis melalui video animasi lagu edukasi pada anak di Desa Drajat Kecamatan Baureno Kabupaten Bojonegoro telah melibatkan 50 peserta. Kegiatan ini dinilai menarik dan edukatif oleh peserta dan orang tua atau wali peserta. Diharapkan setelah anak-anak menonton video, anak-anak dapat melakukan kegiatan anjuran kesehatan pencegahan penyakit Toxoplasmosis sehingga dapat mengurangi dan mencegah penularan penyakit Toxoplasmosis. Orang tua atau wali peserta berharap kegiatan edukasi melalui video animasi lagu akan diperbanyak agar anak -anak lebih banyak menerima lagu edukasi sesuai usia anak terutama tentang kesehatan.

\section{Ucapan Terima Kasih}

Penulis mengucapkan terima kasih kepada masyarakat terutama orang tua atau wali peserta kegiatan di Desa Drajat Kecamatan Baureno Kabupaten Bojonegoro yang telah mengizinkan putra atau putri nya mengikuti kegiatan ini.

\section{Daftar Referensi}

Aditama, N. (2016). Determinan Lingkungan Dan Perilaku Berhubungan Dengan Terjadinya Penyakit Infeksi Toxoplasmosis Di Wilayah Kota Semarang. Jurnal Kesehatan Masyarakat (e-Journal), 4(5), 67-76.

Ariyanto, A. M. (2018). Membangun Sistem Pencegahan dan Pengendalian

Penyakit Zoonosis dan Penyakit Infeksi Emerging (PIE) di Kabupaten

Ketapang Kalimantan Barat Melalui Pendekatan One Health.

Ekowati, U., Nggonggoek, W., \& Utomo, S. S. (2019). Sosialisasi Pendidikan

Karakter Berbasis Budaya Pada Anak-Anak Dengan Media Video. SELAPARANG Jurnal Pengabdian Masyarakat Berkemajuan, 2(2), 19-23.

Hamdan, A. (2015). Toxoplasmosis Dalam Kehamilan. Intisari Sains Medis, Fakultas Kedokteran Universitas Udayana. 2(1), 13-18.

Hasanah, U. (2016). Pengembangan kemampuan fisik motorik melalui permainan tradisional bagi anak usia dini. Jurnal Pendidikan Anak, 5(1). Hastuti, D., Alfiasari, A., \& Chandriyani, C. (2010). Nilai anak, stimulasi psikososial, dan perkembangan kognitif anak usia 2-5 tahun pada keluarga rawan pangan di kabupaten Banjarnegara, Jawa Tengah. Jurnal 
Ilmu Keluarga \& Konsumen, 3(1), 27-34.

Mori, F.M.R., Bregano, R.M., Capobiango, J.D., Inoue, I.T., Reche, E.M.V., Morimoto, H.K., Casella, A.M.B., Bittencourt, L.H.F., Freire, R.L., Navarro, I.T. (2011). Programs for Control of Congenital Toxoplasmosis. Rev AssocMed Bras. 57: 581- 586

Rachmawati, I. (2019). Personal Hygiene and Toxoplasmosis Occurences in "Bungkul Cat Lovers" Cat Owners Community in Surabaya: An Association Study. JURNAL KESEHATAN LINGKUNGAN, 11(2), 116-122.

Sari, N. L. J. W., \& Sudarmaja, I. M. (2017). Gambaran Tingkat Pengetahuan Remaja Putri Terhadap Toksoplasmosis Di SMA 2 Denpasar Tahun 2014. E-Jurnal Medika, 4(1), 1-9.

Sulistyawati, D., \& Tantya, D. P. (2018). Pemeriksaan Ookista Toxoplasma gondii pada Kemangi (Ocimum basilicum) dan Kubis (Brassica oleracea, L.) di Pedagang Ayam dan Ikan Goreng/Panggang. Biomedika, 11(1).

Tuda, J., Adiani, S., Ichikawa-Seki, M., Umeda, K., \& Nishikawa, Y. (2017). Seroprevalence of Toxoplasma gondii in humans and pigs in North Sulawesi, Indonesia. Parasitology international, 66(5), 615-618. 